\title{
KUANTIFIKASI KUALITAS TEMPAT TUMBUH DAN PRODUKTIVITAS TEGAKAN UNTUK HUTAN TANAMAN EUKALIPTUS DI KABUPATEN SIMALUNGUN, SUMATERA UTARA
}

\author{
(The Quantification of Site Quality and Stands Productivity for \\ Eucalypt Plantation Forest at Simalungun District, North Sumatra)
Darwo $^{1}$, Endang Suhendang ${ }^{2}$, I Nengah Surati Jaya ${ }^{2}$, Herry Purnomo ${ }^{2}$, Pratiwi ${ }^{3}$
${ }^{1}$ Pusat Litbang Peningkatan Produktivitas Hutan
Jl. Gunung Batu No. 5 Kotak Pos 331, Bogor - 16610
Telp. 0251-8631238; Fax. 0251-7520005
${ }^{2}$ Fakultas Kehutanan, Institut Pertanian Bogor, Kampus Dramaga
${ }^{3}$ Pusat Litbang Konservasi dan Rehabilitasi
Jl. Gunung Batu No. 5 Kotak Pos 165, Bogor - 16610
Telp. 0251-8633234; Fax. 0251-8633111

Naskah masuk : 6 Februari 2012; Naskah diterima : 1 Mei 2012

\begin{abstract}
The diversity of site quality in eucalypt plantation forest has led to the fluctuation of wood production. Therefore, site quality grouping was needed to be conducted. The research objective were to determine the maximum volume cycle, site index model, class of site quality, the stands growth and yield for each site quality group of eucalypt plantation forest. Data were collected from 343 permanent sample plots. Plots were circular with radius of $11.28 \mathrm{~m}$ (approximately $0.02 \mathrm{ha}$ ). Stands characteristics were analyzed using regression, then transformed into logarithmic as a basic for site quality grouping. Analytical results showed that the maximum volume cycle is 8 (eight) years old, then the site index age is 8 (eight) years with the average of stands volume is $249.34 \mathrm{~m}^{3} \mathrm{ha}^{-1}$ and mean annual increment is $31.17 \mathrm{~m}^{3} \mathrm{ha}^{-1} \mathrm{yr}^{-1}$. The site index model (S) is $\log S=\log O h+0.6944\left(A^{-1}-8^{-1}\right)$ where Oh = the average dominant height $(\mathrm{m}), A=$ the age of stands (years), and $8=$ the site index age of 8 (eight) years. Its reclassified into 4 (four) classes of site quality (bonita). The mean annual increment in bonita I, II, III, and IV were respectively $20.95 \mathrm{~m}^{3} \mathrm{ha}$ ${ }^{l} y r^{-1}, 32.40 \mathrm{~m}^{3} \mathrm{ha}^{-1} \mathrm{yr}^{-1}, 37.15 \mathrm{~m}^{3} \mathrm{ha}^{-1} \mathrm{yr}^{-1}$, and $40.25 \mathrm{~m}^{3} \mathrm{ha}^{-1} \mathrm{yr}^{-1}$. The average stands volume in bonita I, II, III, and IV were respectively $167.58 \mathrm{~m}^{3} \mathrm{ha}^{-1}, 259.17 \mathrm{~m}^{3} \mathrm{ha}^{-1}, 297.17 \mathrm{~m}^{3} \mathrm{ha}^{-1}$, and $321.98 \mathrm{~m}^{3} \mathrm{ha}^{-1}$.
\end{abstract}

Keywords: Site index, site quality, cycle, eucalypt, and increment

\begin{abstract}
ABSTRAK
Keragaman kualitas tempat tumbuh di hutan tanaman eukaliptus telah menimbulkan produksi kayu yang berfluktuasi. Untuk itu, perlu dilakukan pengelompokan kualitas tempat tumbuh. Tujuan penelitian adalah menentukan daur volume maksimum, model indeks tempat tumbuh, kelas kualitas tempat tumbuh, dan tingkat pertumbuhan dan hasil tegakan untuk masing-masing kelas kualitas tempat tumbuh hutan tanaman eukaliptus. Data dihimpun dari 343 petak contoh permanen. Bentuk plot lingkaran dengan berjari-jari 11,28 m (luas 0,02 ha). Karakteristik tegakan dianalisis menggunakan regresi yang ditransformsikan ke logaritmik dan dilakukan pengelompokan kualitas tempat tumbuh. Hasil analisis diperoleh daur volume maksimum adalah 8 (delapan) tahun, sehingga umur indeks tempat tumbuh 8 (delapan) tahun dengan rata-rata volume tegakan $249,34 \mathrm{~m}^{3} /$ ha dan riap tahunan rata-rata 31,17 $\mathrm{m}^{3} / \mathrm{ha} /$ tahun. Model indeks tempat tumbuh (S) adalah $\log \mathrm{S}=\log \mathrm{Oh}+0,69441\left(\mathrm{~A}^{-1}-8^{-1}\right)$, dimana; $\mathrm{Oh}=$ peninggi ( $\mathrm{m}$ ), $\mathrm{A}=$ umur tegakan (tahun), dan $8=$ umur indeks tempat tumbuh 8 (delapan) tahun. Indeks tempat tumbuh tersebut dikelompokan menjadi 4 (empat) kelas kualitas tempat tumbuh (bonita). Riap tahunan rata-rata di bonita I, II, III, dan IV berturut-turut adalah $20,95 \mathrm{~m}^{3} / \mathrm{ha} / \mathrm{tahun}, 32,40 \mathrm{~m}^{3} / \mathrm{ha} / \mathrm{tahun}$, $37,15 \mathrm{~m}^{3} /$ ha/tahun, dan $40,25 \mathrm{~m}^{3} /$ ha/tahun. Rata-rata volume tegakan di bonita I, II, III, IV berturut-turut adalah $167,58 \mathrm{~m}^{3} /$ ha, $259,17 \mathrm{~m}^{3} /$ ha. $297,17 \mathrm{~m}^{3} /$ ha, dan $321,98 \mathrm{~m}^{3} / \mathrm{ha}$.
\end{abstract}

Kata kunci : Indeks tempat tumbuh, kualitas tempat tumbuh, daur, eukaliptus, riap 


\section{PENDAhuluan}

Hutan tanaman eukaliptus merupakan salah satu jenis prioritas yang dikembangkan dalam pengelolaan hutan tanaman di Indonesia yang diperuntukkan sebagai kayu serat (pulp). Kriteria jenis yang dikembangkan untuk hutan tanaman pulp, yaitu dipilih jenis cepat tumbuh, produktivitas tegakan tinggi, daur pendek dan memiliki sifat (kimia dan fisika) kayu sesuai dengan persyaratan bahan baku industri pulp (Mindawati et al., 2010). Eukaliptus cocok dikembangkan di daerah tropis (Harwood, 1998; Leksono, 2010), dipanen pada umur 6 - 7 tahun (Quilho et al., 2006), dan layak untuk bahan baku pulp pada umur 4 - 5 tahun (Sihite, 2008).

Setelah terpenuhinya persyaratan tumbuh diblapangan,btimbul permasalahan produktivitas tegakan antara lokasi satu dengan lainnya berfluktuasi. Hal ini, diakibatkan adanya keragaman kualitas tempat tumbuh. Kualitas tempat tumbuh sebagai potensi produksi kayu dari suatu tapak bagi jenis tertentu atau hutan tertentu (Avery dan Burkhart, 2002). Potensi produksi tersebut merupakan resultanse dari interaksi antara jenis yang bersangkutan dengan berbagai faktor, meliputi kondisi tanah, iklim dan karakteristik topografi (Husch et al., 2003). Fluktuasi panenan kayu telah menimbulkan prospek pengelolaan hutan tanaman yang tidak baik
(Kuncahyo, 2006).

Untuk mengatasi terjadinya fluktuasi hasil panenan kayu tersebut, maka perlu pengelompokkan kualitas tempat tumbuh. Kualitas tempat tumbuh dapat digunakan sebagai dasar pendelenasian kawasan hutan ke dalam unit-unit pengelolaan yang homogen. Tujuan penelitian ini adalah (1) menentukan daur volume maksimum, (2) model indeks tempat tumbuh, (3) kelas kualitas tempat tumbuh (bonita), dan (4) tingkat pertumbuhan dan hasil tegakan untuk setiap kelas kualitas tempat tumbuh hutan tanaman eukaliptus.

\section{METODE PENELITIAN}

\section{A. Waktu dan Tempat Penelitian}

Penelitian dilakukan mulai Oktober 2010 sampai dengan Desember 2011. Lokasi penelitian di Kawasan Hutan Tanaman PT Toba Pulp Lestari (PT TPL) Sektor Aek Nauli, dan menurut wilayah administrasi termasuk ke dalam Kabupaten Simalungun, Provinsi Sumatera Utara. Secara geografis terletak antara $02^{\circ} 40^{\prime} 00^{\prime \prime}$ - $02^{\circ} 50^{\prime} 00^{\prime \prime} \mathrm{LU}$ dan $98^{\circ} 50^{\prime} 00^{\prime \prime}$ - 99 $99^{\circ} 10^{\prime} 00^{\prime \prime} \mathrm{BT}$ dan berada pada ketinggian $450-1.300 \mathrm{~m}$ di atas permukaan laut. Peta lokasi penelitian dapat dilihat pada Gambar 1.

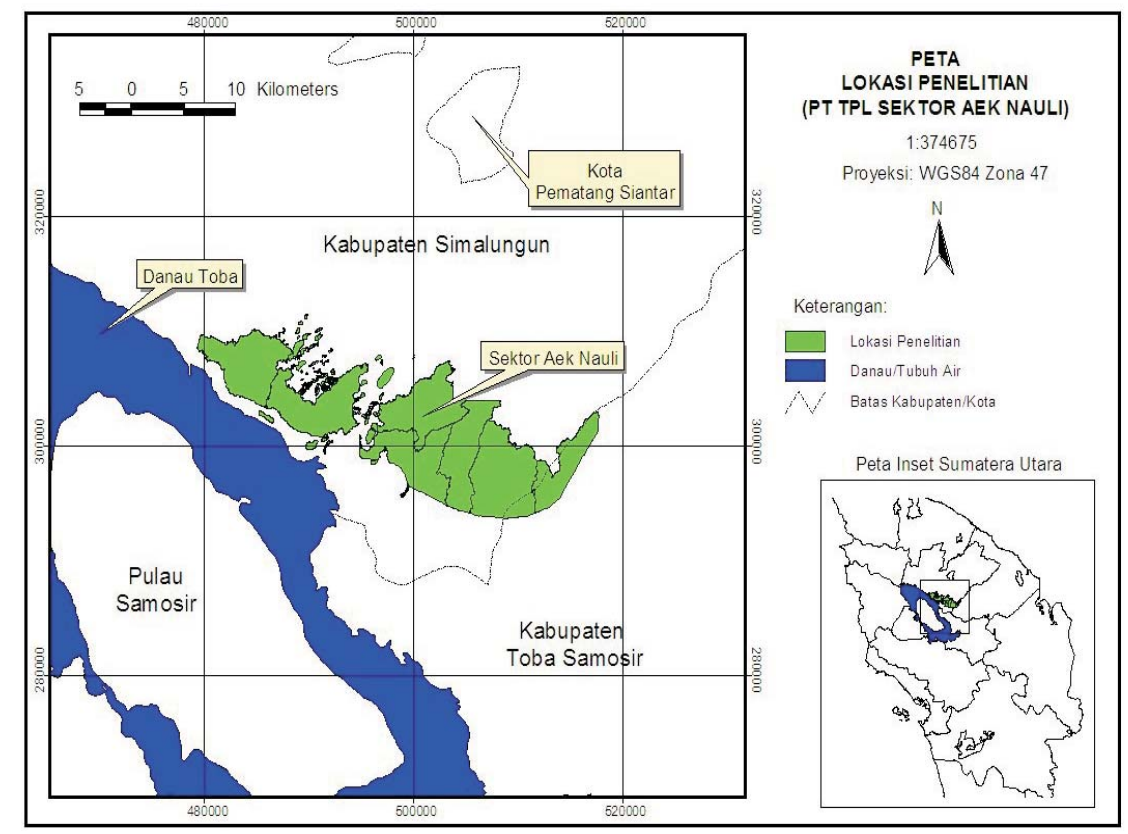

Gambar(Figure) 1. Peta lokasi penelitian di Sektor Aek Nauli PT Toba Pulp Lestari (The research area at Aek Nauli Sector of PT Toba Pulp Lestari) 


\section{B. Bahan Penelitian}

Petak Contoh Permanen (Permanent Sample Plot $=$ PSP) tanaman sebagai obyek penelitian dengan luas PSP 0,02 ha dalam bentuk lingkaran dengan jari-jari 11,28 $\mathrm{m}$.

Selanjutnya data dipilah secara acak menjadi dua bagian, yaitu 263 PSP digunakan untuk bahan penyusunan model dan 80 PSP digunakan untuk validasi model. Pengelompokkan kelas umur sebagai berikut; kelas umur I (umur tegakan antara 0 - 1 tahun), kelas umur II (umur tegakan antara 1 - 2 tahun), kelas umur III (umur tegakan antara 2 - 3 tahun), kelas umur IV (umur tegakan antara 3 - 4 tahun), kelas umur V (umur tegakan antara 4 - 5 tahun), dan kelas VI (umur tegakan antara 5 - 6 tahun). Eukaliptus ditanam dengan jarak tanam $2 \mathrm{~m} \times 3 \mathrm{~m}$. Diskripsi sebaran umur tegakan hutan tanaman eukaliptus yang dijadikan bahan penelitian dapat dilihat pada Tabel 1.

Tabel (Table) 1. Pengelompokkan data PSP (The grouping of PSP data)

\begin{tabular}{|c|c|c|c|}
\hline \multirow[b]{2}{*}{ No. } & \multirow[b]{2}{*}{ Kelas umur (Group of age) } & \multicolumn{2}{|c|}{ Jumlah data PSP (Number of PSP data) } \\
\hline & & $\begin{array}{c}\text { Penyusunan model } \\
\text { (Preparation of model) }\end{array}$ & $\begin{array}{c}\text { Validasi model } \\
\text { (Validation of model) }\end{array}$ \\
\hline 1 & $\mathrm{I}$ & 107 data & 49 data \\
\hline 2 & II & 6 data & 2 data \\
\hline 3 & III & 122 data & 26 data \\
\hline 4 & IV & 4 data & - \\
\hline 5 & $\mathrm{~V}$ & 18 data & 3 data \\
\hline 6 & VI & 6 data & - \\
\hline & Total data (Total of data) & 263 data & 80 data \\
\hline
\end{tabular}

\section{Metode}

Data parameter pertumbuhan tegakan yang dikumpulkan dari PSP yaitu peninggi, diameter, tinggi total, dan volume tegakan. Peninggi adalah nilai rata-rata tinggi sejumlah pohon berdiameter terbesar atau pohon-pohon dominan dan ko-dominan yang letaknya tersebar merata di suatu areal, dan istilah peninggi di Indonesia dimaknai sebagai ratarata tinggi dari pohon-pohon tertinggi yang letaknya tersebar merata dalam satu hektar areal, maka pada masing-masing PSP dipilih pohon tertinggi sebagai pohon peninggi (Harbagung, 2009). Diameter adalah nilai ratarata diameter setinggi dada sejumlah pohon dalam PSP. Tinggi adalah nilai rata-rata tinggi total sejumlah pohon dalam PSP. Volume tegakan adalah nilai sejumlah volume pohon yang ada dalam PSP yang dinyatakan dalam $\mathrm{m}^{3} / \mathrm{ha}$. Besaran masing-masing parameter tersebut ditentukan menurut (Avery dan Burkhart, 2002; Husch et al., 2003):

\section{Penyusunan model persamaan}

Model persamaan yang disusun meliputi:

a. Model pertumbuhan dan hasil tegakan menurut Alder (1980) yaitu menduga dia- meter, tinggi, dan volume tegakan. Selanjutnya menentukan riap tahunan rata-rata (Mean Annual Increment - MAI), riap tahun berjalan (Current Annual Increment - CAI), daur volume maksimum (Pordan, 1968; Simon, 2010).

b. Model indeks tempat tumbuh (site index) disusun berdasarkan hubungan matematis antara peninggi $(\mathrm{Oh})$, umur tegakan $(\mathrm{A})$ dan umur indeks dalam bentuk model sigmoid yang ditransformasikan ke bentuk logaritmik (Avery dan Burkhart, 2002).

c. Nilai-nilai indeks tempat tumbuh yang telah diperoleh, kemudian ditentukan nilai rata-rata indeks tempat tumbuh, standar deviasi, nilai minimum dan maksimumnya. Selanjutnya nilai-nilai tersebut digunakan untuk menentukan kelas kualitas tempat tumbuh (bonita) dengan interval antar bonita sebesar nilai standar deviasi dari nilai indeks tempat tumbuh di lokasi penelitian.

d. Penyusunan model hubungan regresi ganda. Untuk mendugaan diameter dan volume tegakan di setiap kelas kualitas tempat tumbuh, maka ditentukan dengan membuat hubungan antara peubah tak bebas (diameter, tinggi, dan volume tegakan) dengan peubah bebas (umur dan kerapatan bidang dasar 
tegakan). Model persamaannya disusun dalam bentuk regresi ganda: (1) In $\mathrm{D}=\mathrm{a}_{0}+\mathrm{a}_{1}\left(\mathrm{~A}^{-1}\right)+\mathrm{a}_{2} \ln (\mathrm{BA}) ;(2) \ln \mathrm{H}=\mathrm{b}_{0}+\mathrm{b}_{1}$ $\left(\mathrm{A}^{-1}\right)+\mathrm{b}_{2} \ln (\mathrm{BA}) ;$ dan (3) $\ln \mathrm{V}=\mathrm{c}_{0}+\mathrm{c}_{1}\left(\mathrm{~A}^{-1}\right)+$ $\mathrm{c}_{2} \ln (\mathrm{BA})$. Dimana, $\mathrm{D}=$ diameter tegakan (cm); V = volume tegakan $\left(\mathrm{m}^{3} / \mathrm{ha}\right) ; \mathrm{A}=$ umur tegakan, $\mathrm{BA}=$ kerapatan bidang dasar $\left(\mathrm{m}^{2} / \mathrm{ha}\right) ; \mathrm{a}_{1}, \mathrm{a}_{2}, \mathrm{~b}_{1}, \mathrm{~b}_{2}, \mathrm{c}_{1}, \mathrm{c}_{2}=$ koefisien regresi; $\mathrm{a}_{0}, \mathrm{~b}_{0}, \mathrm{c}_{0}=$ intersep.

\section{Pengujian model persamaan}

Model yang telah disusun dilakukan analisis ragam, analisis determinasi, dan validasi model (Matjik dan Sumertajaya, 2002; Supranto, 2005; Kutner et al., 2005). Validasi model dilakukan dengan menggunakan data contoh yang tidak digunakan dalam penyusunan model yang dibuat. Uji validasi model meliputi: (a) akar rata-rata kuadrat sisaan (Root Mean Square Error - RMSE), (b) persen akar rata-rata kuadrat sisaan (Root Mean Square Percent Error - RMSPE), dan (c) uji Khi-kuadrat (Khi-square test). Suatu model dari hasil analisis regresi dikatakan baik, apabila nilai koefisien regresi signifikan, memiliki koefisen determinasi tinggi, dan memiliki keandalan dalam hal keakuratan (sisaan yang rendah), yaitu model yang mampu memberikan nilai estimasi yang akurat (nilai dugaan mendekati nilai aktual sehingga sisaan mendekati nol).

\section{HASIL DAN PEMBAHASAN}

\section{A. Hasil}

\section{Model persamaan regresi}

Hasil analisis regresi hubungan peninggi, diameter, tinggi, dan volume tegakan eukaliptus di lokasi penelitian disajikan dapat dilihat pada Tabel 2. Dari hasil analisis ragam untuk semua persamaan pada Tabel 2 menunjukkan nilai $\mathrm{F}_{\text {hitung }}$ lebih besar daripada $\mathrm{F}_{\text {tabel }}(\mathrm{p}$-value $=0)$. Hasil uji- $\mathrm{t}$ diperoleh nilai $t_{\text {hitung }}$ untuk koefisien regresi lebih besar daripada $\mathrm{t}_{\text {tabel }}(\mathrm{p}$-value $=0)$ yang berarti bahwa umur tegakan berpengaruh sangat nyata terhadap peninggi, diameter, tinggi, dan volume tegakan pada tingkat nyata 5\%. Simpangan baku dari model yang telah disusun termasuk kecil dan koefisen determinasi $\left(\mathrm{R}^{2}\right)$ relatif tinggi (di atas 94\%). Hasil uji validasi diperoleh rata-rata kesalahan penduga model (RMSE) untuk peninggi, diameter, tinggi total, dan volume tegakan masingmasing adalah $0,24 \mathrm{~m} ; 0,26 \mathrm{~m} ; 0,26 \mathrm{~m}$; dan 0,72 $\mathrm{m}^{3} /$ ha dengan persentase kesalahan prediksinya (RMSPE) masing-masing adalah 3,21\%; 2,64\%; $0,26 \%$; dan $8,95 \%$ dari nilai sebenarnya. Hasil uji $\mathrm{X}^{2}$ (Khi-kuadrat) dari keempat persamaan pada Tabel 2 di atas menunjukkan hasil yang tidak berbeda nyata pada tingkat kepercayaan 95\%. Dengan demikian, model persamaan yang dibuat bisa digunakan untuk menduga peninggi, diameter, tinggi, dan volume tegakan.

Tabel(Table) 2. Hubungan antara peninggi, diameter, tinggi dan volume tegakan dengan umur tegakan eukaliptus (The relationship between dominant height, diameter, height, and stands volume with stands age of eucalypt)

\begin{tabular}{|c|c|c|c|c|c|c|c|c|}
\hline \multirow[b]{2}{*}{ No. } & \multirow{2}{*}{$\begin{array}{l}\text { Model persamaan } \\
\text { (The model equations) }\end{array}$} & \multirow{2}{*}{$\begin{array}{l}\text { Simpangan baku } \\
\text { (Standard error) }\end{array}$} & \multirow[b]{2}{*}{$\mathrm{R}^{2}$} & \multirow[b]{2}{*}{$\mathrm{R}^{2}$-adj } & \multirow{2}{*}{$\begin{array}{l}\text { RMSE } \\
(\mathrm{m})\end{array}$} & \multirow{2}{*}{$\begin{array}{c}\text { RMSPE } \\
(\%)\end{array}$} & \multicolumn{2}{|c|}{ Chi-square } \\
\hline & & & & & & & $\begin{array}{l}\text { Hitung } \\
\text { (Value) }\end{array}$ & $\begin{array}{l}\text { Tabel } \\
(\text { Table })\end{array}$ \\
\hline 1 & $\log \mathrm{Oh}=1,4809-0,6944 \mathrm{~A}^{-1}$ & 0,0420 & 0,971 & 0,971 & 0,24 & 3,21 & $10.929^{\text {tn }}$ & 101,88 \\
\hline 2 & $\ln \mathrm{D}=3,0191-1,6133 \mathrm{~A}^{-1}$ & 0,1127 & 0,962 & 0,962 & 0,26 & 2,64 & $7.387^{\mathrm{tn}}$ & \\
\hline 3 & $\ln \mathrm{H}=3,2252-1,6838 \mathrm{~A}^{-1}$ & 0,1298 & 0,954 & 0,954 & 0,26 & 0,26 & $8.760^{\text {tn }}$ & \\
\hline 4 & $\ln V=6,4649-7,5683 \mathrm{~A}^{-1}$ & 0,6366 & 0,946 & 0,946 & 0,72 & 8,95 & $84.874^{\text {tn }}$ & \\
\hline
\end{tabular}

Keterangan (Remarks) : $\mathrm{tn}=$ tidak berbeda nyata pada tingkat nyata $5 \%$ (non significant at $5 \%$ level)

$\mathrm{Oh}=$ peninggi/average dominant height $(\mathrm{m}), \mathrm{D}=$ diameter setinggi dada/diameter at breast height $(\mathrm{cm})$, $\mathrm{H}=$ tinggi/height $(\mathrm{m}), \mathrm{V}=$ volume tegakan/stands volume $\left(\mathrm{m}^{3} / \mathrm{ha}\right)$, dan $\mathrm{A}=$ umur tegakan $/$ stands age (tahun/years).

\section{Model indeks tempat tumbuh}

Dari hasil hubungan antara peninggi dengan umur tegakan, maka model indeks tempat tumbuh $(\mathrm{S})$ adalah $\log \mathrm{S}=\log \mathrm{Oh}+0.69441$ $\left(\mathrm{A}^{-1}-8^{-1}\right)$, dimana $\mathrm{Oh}=$ peninggi $(\mathrm{m}), \mathrm{A}=$ umur tegakan (tahun), dan $8=$ umur indeks 8 (delapan) tahun. Hasil analisis diperoleh rata-rata nilai indeks tempat tumbuh pada tegakan eukaliptus sebesar 25 meter, standar deviasi 3 (tiga) meter dengan nilai terendah 18 meter dan tertinggi 34 meter. Dari persamaan tersebut dapat ditentukan nilai-nilai indeks tempat tumbuh setiap plot 
contoh sehingga sebaran nilai indeks tempat tumbuh yang ada di areal hutan tanaman eukaliptus PT Toba Pulp Lestari Sektor Aek Nauli dapat diketahui.

\section{Kelas kualitas tempat tumbuh (Bonita)}

Nilai-nilai indeks tempat tumbuh yang telah diperoleh, selanjutnya digunakan untuk penentuan kelas kualitas tempat tumbuh (bonita) dengan interval antar bonita sebesar 3 (tiga) meter. Dasar penentuan interval tersebut berdasarkan besarnya standar deviasi dari nilai indeks tempat tumbuh di lokasi penelitian.
Dengan demikian, bonita dibuat menjadi 4 (empat), yaitu bonita I, II, III, dan IV (Tabel 3 dan Gambar 2).

Kualitas tempat tumbuh di setiap kelas sebagai berikut:

a. Bonita I, peninggi pada umur 8 (delapan) tahun kurang dari $22 \mathrm{~m}$ (rendah).

b. Bonita II, peninggi pada umur 8 (delapan) tahun antara $22-25 \mathrm{~m}$ (sedang).

c. Bonita III, peninggi pada umur 8 (delapan) tahun antara $25-28 \mathrm{~m}$ (tinggi).

d. Bonita IV, peninggi pada umur 8 (delapan) tahun lebih dari $28 \mathrm{~m}$ (sangat tinggi).

Tabel(Table) 3. Peninggi tegakan eukaliptus di setiap bonita (The average dominant height of eucalypt stands in each bonita/group of site index)

\begin{tabular}{|c|c|c|c|c|}
\hline \multirow{2}{*}{$\begin{array}{c}\text { Umur }(\text { Age }) \\
\text { (Tahun) }(\text { Years })\end{array}$} & \multicolumn{4}{|c|}{ Peninggi (The average dominant height) (m) } \\
\cline { 2 - 5 } & Bonita I & Bonita II & Bonita III & Bonita IV \\
\hline 1 & $<5,4$ & $5,4-6,2$ & $6,3-6,9$ & $>6,9$ \\
\hline 2 & $<12,1$ & $12,1-13,7$ & $13,8-15,4$ & $>15,4$ \\
\hline 3 & $<15,8$ & $15,8-17,9$ & $18,0-20,1$ & $>20,1$ \\
\hline 4 & $<18,0$ & $18,0-20,5$ & $20,6-22,9$ & $>22,9$ \\
\hline 5 & $<19,5$ & $19,5-22,2$ & $22,3-24,8$ & $>24,8$ \\
\hline 6 & $<20,6$ & $20,6-23,4$ & $23,5-26,2$ & $>26,2$ \\
\hline 7 & $<21,4$ & $21,4-24,3$ & $24,4-27,2$ & $>27,2$ \\
\hline 8 & $<22,0$ & $22,0-25,0$ & $25,1-28,0$ & $>28,0$ \\
\hline
\end{tabular}

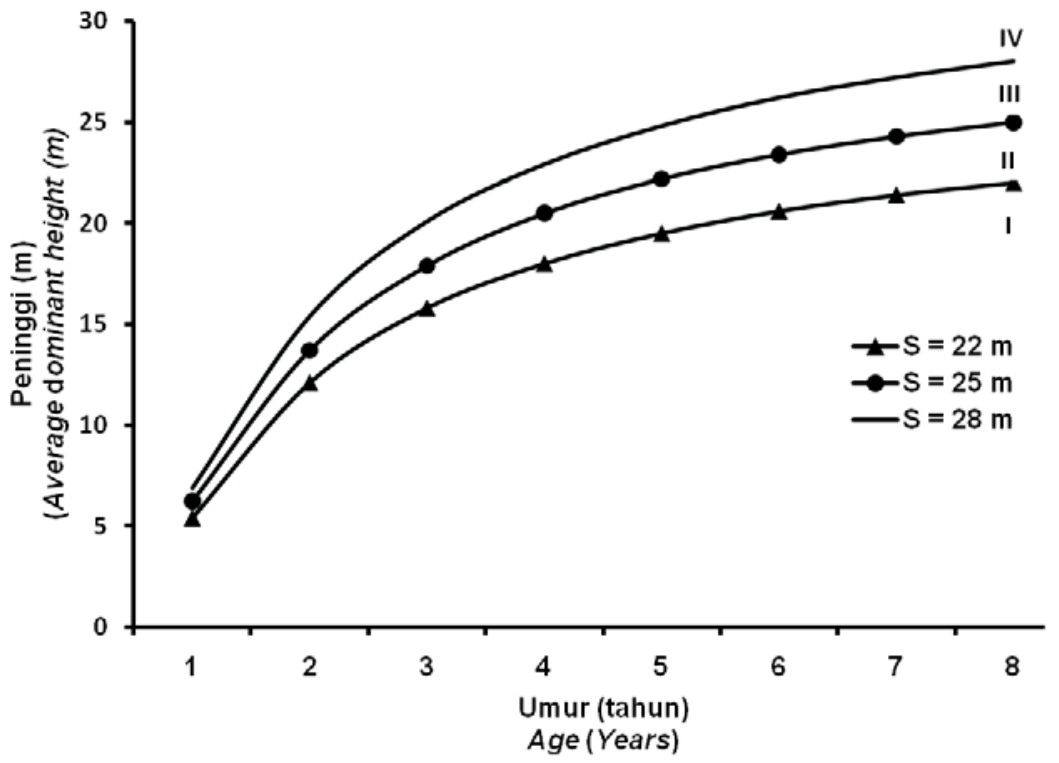

Gambar (Figure) 2. Kurva peninggi untuk tegakan eukaliptus di setiap bonita (Curves of the average dominant height for eucalypt stands in each bonita) 


\section{Pendugaan diameter, tinggi dan volume tegakan di setiap kelas kualitas tempat tumbuh}

Hasil analisis regresi hubungan diameter, tinggi, dan volume tegakan oleh umur tegakan dan kerapatan bidang dasar untuk masing-masing kelas kualitas tempat tumbuh menunjukkan hubungan yang sangat nyata $\left(\mathrm{p}_{\text {-value }}=0\right)$. Namun antar peubah bebas terjadi korelasi yang kuat (terjadi mulikolinearisasi) dan setelah dianalisis regresi bertatar (regression stepwaise) menjadi persamaan dengan peubah bebasnya adalah umur tegakan. Model persamaannya disajikan pada Tabel 4.

Hasil uji validasi model pendugaan dia- meter, tinggi, dan volume tegakan untuk semua kelas kualitas tempat tumbuh diperoleh masingmasing nilai RMSE antara $0,46-1,14 \mathrm{~cm}, 0,47$ $1,22 \mathrm{~m}$, dan $3,48-6,48 \mathrm{~m}^{3} / \mathrm{ha}$. Persentase kesalahan prediksi diameter, tinggi, dan volume tegakan terhadap nilai sebenarnya masingmasing sebesar 1,76-4,26\%, 1,27 - 4,01\%, dan 2,07 - 7,09\%. Dan hasil uji $X^{2}$ (Khi-kuadrat) persamaan pada Tabel 4 di atas menunjukkan hasil yang tidak berbeda nyata pada tingkat keper-cayaan 95\%. Dengan demikian, model persa-maan yang dibuat bisa digunakan untuk menduga diameter, tinggi, dan volume tegakan untuk masing-masing kelas kualitas tempat tumbuh.

Tabel(Table) 4. Model pendugaan diameter, tinggi dan volume tegakan untuk setiap bonita (The prediction models of dominant height, diameter, height, and stands volume for each bonita)

\begin{tabular}{|c|c|c|c|c|c|c|c|c|}
\hline \multirow[b]{2}{*}{ No. } & \multirow{2}{*}{$\begin{array}{l}\text { Model persamaan } \\
\text { (The model equations) }\end{array}$} & \multirow{2}{*}{$\begin{array}{l}\text { Simpangan baku } \\
\text { (Standard error) }\end{array}$} & \multirow[b]{2}{*}{$\mathrm{R}^{2}$} & \multirow[b]{2}{*}{$\mathrm{R}^{2}$-adj } & \multirow[b]{2}{*}{ RMSE (m) } & \multirow{2}{*}{$\begin{array}{l}\text { RMSPE } \\
(\%)\end{array}$} & \multicolumn{2}{|c|}{ Chi-square } \\
\hline & & & & & & & $\begin{array}{l}\text { Hitung } \\
\text { (Value) }\end{array}$ & \begin{tabular}{c|} 
Tabel \\
(Table $)$
\end{tabular} \\
\hline 1. & $\begin{array}{l}\text { Bonita } \\
\text { a. } \ln \mathrm{D}=2,9448-1,6967 \mathrm{~A}^{-1} \\
\text { b. } \ln \mathrm{H}=3,0463-1,6975 \mathrm{~A}^{-1} \\
\text { c. } \ln \mathrm{V}=6,1336-8,0972 \mathrm{~A}^{-1}\end{array}$ & $\begin{array}{l}0,0950 \\
0,0952 \\
0,3803\end{array}$ & $\begin{array}{l}0,978 \\
0,978 \\
0,984\end{array}$ & $\begin{array}{l}0,977 \\
0,979 \\
0,984\end{array}$ & $\begin{array}{l}1,14 \mathrm{~cm} \\
0,90 \mathrm{~m} \\
6,48 \mathrm{~m}^{3} / \mathrm{ha}\end{array}$ & $\begin{array}{l}3,79 \\
2,67 \\
2,07\end{array}$ & $\begin{array}{l}1,87^{\text {tn }} \\
0,93^{\text {tn }} \\
0,43^{\text {tn }}\end{array}$ & $\begin{array}{l}5,89 \\
5,89 \\
5,89\end{array}$ \\
\hline 2. & $\begin{array}{l}\text { Bonita II } \\
\text { a. } \ln \mathrm{D}=3,0949-1,6530 \mathrm{~A}^{-1} \\
\text { b. } \ln \mathrm{H}=3,1847-1,6998 \mathrm{~A}^{-1} \\
\text { c. } \ln \mathrm{V}=6,5730-8,1242 \mathrm{~A}^{-1}\end{array}$ & & $\begin{array}{l}0,973 \\
0,979 \\
0,972 \\
\end{array}$ & $\begin{array}{l}0,973 \\
0,979 \\
0,972 \\
\end{array}$ & $\begin{array}{l}0,46 \mathrm{~cm} \\
0,47 \mathrm{~m} \\
3,48 \mathrm{~m}^{3} / \mathrm{ha}\end{array}$ & $\begin{array}{l}1,76 \\
1,27 \\
5,30 \\
\end{array}$ & $\begin{array}{r}6,70^{\text {tn }} \\
2,50^{\text {tn }} \\
34,06^{\text {tn }} \\
\end{array}$ & $\begin{array}{l}34,76 \\
34,76 \\
34,76 \\
\end{array}$ \\
\hline 3. & $\begin{array}{l}\text { Bonita III } \\
\text { a. } \ln \mathrm{D}=3,0314-1,0115 \mathrm{~A}^{-1} \\
\text { b. } \ln \mathrm{H}=3,2550-1,6227 \mathrm{~A}^{-1} \\
\text { c. } \ln \mathrm{V}=6,5658-6,9719 \mathrm{~A}^{-1}\end{array}$ & $\begin{array}{l}0,0869 \\
0,0805 \\
0,4944\end{array}$ & $\begin{array}{l}0,975 \\
0,980 \\
0,961 \\
\end{array}$ & $\begin{array}{l}0,975 \\
0,980 \\
0,960\end{array}$ & $\begin{array}{l}1,32 \mathrm{~cm} \\
1,22 \mathrm{~m} \\
4,85 \mathrm{~m}^{3} / \mathrm{ha}\end{array}$ & $\begin{array}{l}4,26 \\
4,01 \\
5,65\end{array}$ & $\begin{array}{l}24,66^{\text {tn }} \\
28,98^{\text {tn }} \\
24,03^{\text {tn }}\end{array}$ & $\begin{array}{l}29,81 \\
29,81 \\
29,81 \\
\end{array}$ \\
\hline 4. & $\begin{array}{l}\text { Bonita IV } \\
\text { a. } \ln \mathrm{D}=3,0675-1,5534 \mathrm{~A}^{-1} \\
\text { b. } \ln \mathrm{H}=3,4022-1,7445 \mathrm{~A}^{-1} \\
\text { c. } \ln \mathrm{V}=6,5971-6,5809 \mathrm{~A}^{-1}\end{array}$ & $\begin{array}{l}0,0984 \\
0,1050 \\
0,3000\end{array}$ & $\begin{array}{l}0,969 \\
0,972 \\
0,984\end{array}$ & $\begin{array}{l}0,968 \\
0,971 \\
0,983\end{array}$ & $\begin{array}{l}0,97 \mathrm{~cm} \\
0,63 \mathrm{~m} \\
5,66 \mathrm{~m}^{3} / \mathrm{ha}\end{array}$ & $\begin{array}{l}2,79 \\
1,90 \\
7,09\end{array}$ & $\begin{array}{l}1,32^{\text {tn }} \\
0,62^{\text {tn }} \\
8,54^{\text {tn }}\end{array}$ & $\begin{array}{l}8,57 \\
8,57 \\
8,57 \\
\end{array}$ \\
\hline
\end{tabular}

Keterangan (Remarks): $\mathrm{tn}=$ tidak berbeda nyata pada tingkat nyata $5 \%$ (non significant at $5 \%$ level)

$\mathrm{D}=$ diameter setinggi dada/diameter at breast height $(\mathrm{cm}), \mathrm{H}=$ tinggi/height $(\mathrm{m}), \mathrm{V}=$ volume tegakan/stands volume $\left(\mathrm{m}^{3} / \mathrm{ha}\right)$, dan $\mathrm{A}=$ umur tegakan/stands age (tahun/years).

\section{Model pertumbuhan dan hasil tegakan}

Gambar 3 dan 4 menggambarkan pertumbuhan dan hasil rata-rata diameter, tinggi total dan volume tegakan eukaliptus. Riap volume maksimum sebesar $31,13 \mathrm{~m}^{3} /$ ha/tahun terjadi pada umur 8,1 tahun, riap diameter maksimum $4,4 \mathrm{~cm} /$ tahun pada saat berumur 2,3 tahun dan pada umur 2,4 tahun tercapai riap tinggi maksimum 5,2 m/tahun. Dengan demikian, daur volume maksimum tegakan eukaliptus terjadi pada umur 8,1 tahun, sehingga daurnya ditetapkan 8 (delapan) tahun. Pada daur 8 (delapan) tahun diperoleh rata-rata:
1. Diameter sebesar $16,7 \mathrm{~cm}$ dengan MAI 2,1 $\mathrm{cm} /$ tahun, dan CAI 0,5 cm/tahun.

2. Tinggi sebesar $20,4 \mathrm{~m}$ dengan MAI 2,5 $\mathrm{m} /$ tahun, dan CAI $0,6 \mathrm{~m} /$ tahun.

3. Volume tegakan sebesar $249,34 \mathrm{~m}^{3} /$ ha dengan MAI $31,17 \mathrm{~m}^{3} / \mathrm{ha} /$ tahun, dan CAI 31,52 $\mathrm{m}^{3} / \mathrm{ha} /$ tahun.

Dari hasil pengkelasan kualitas tempat ternyata terjadi perbedaan daur volume maksimum di setiap bonita, yaitu bonita I dan II daur volume maksimum terjadi pada umur 8,2 tahun, sedangkan bonita III dan IV terjadi pada umur 7,1 tahun. Begitu juga setiap bonita menghasikan 


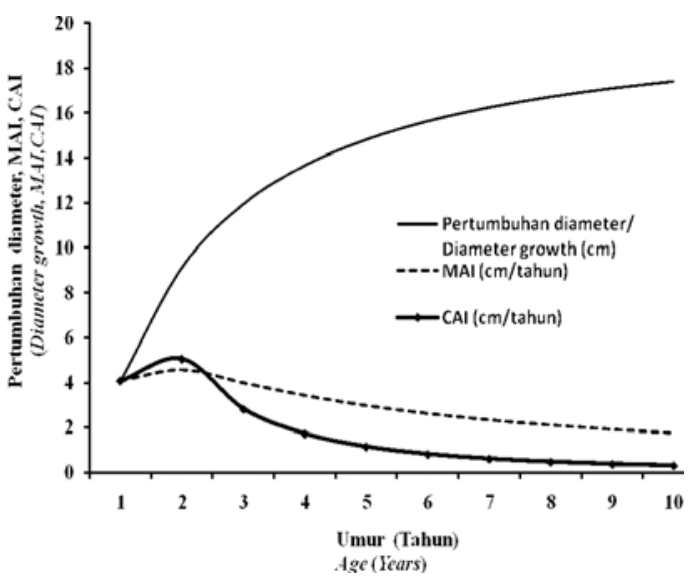

(i)

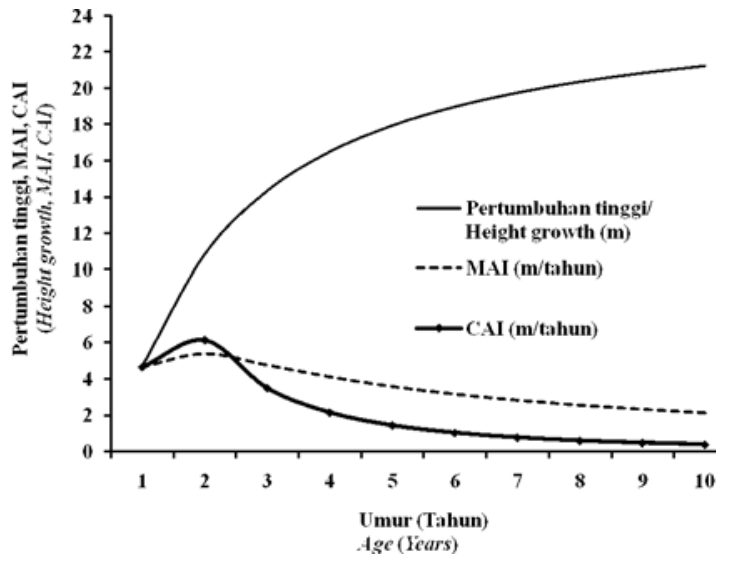

(ii)

Gambar(Figure) 3. Kurva pertumbuhan diameter (i), dan pertumbuhan tinggi (ii) tegakan eukaliptus (The growth curves of diameter (i), height growth (ii) for stands eucalypt)

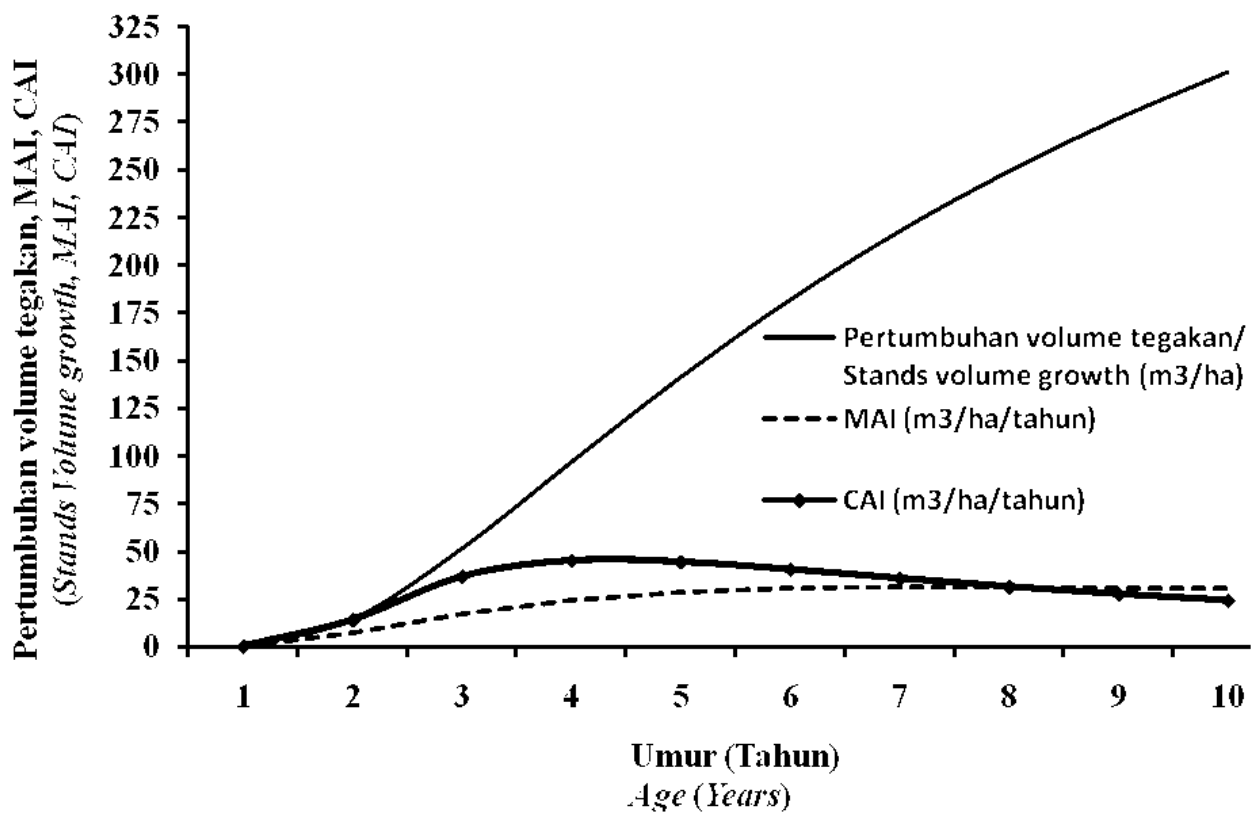

Gambar (Figure) 4. Kurva pertumbuhan volume tegakan eukaliptus (The growth curves of stands volume of eucalypt)

riap tahunan rata-rata antara $20,95-40,86 \mathrm{~m}^{3} / \mathrm{ha} /$ tahun dan rata-rata volume tegakan berkisar $171,77-290,10 \mathrm{~m}^{3} /$ ha (Tabel 5).

Jika dilakukan penebangan pada umur yang berbeda akan dihasilkan sebagai berikut:

1. Daur tebang 5 (lima) tahun diperoleh riap tahunan rata-rata berkisar 18,26 - 39,31 $\mathrm{m}^{3} / \mathrm{ha} / \mathrm{tahun}$ dan rata-rata volume tegakan antara $91,50-196,55 \mathrm{~m}^{3} / \mathrm{ha}$.

2. Daur tebang 6 (enam) tahun diperoleh riap tahunan rata-rata antara $19,93-40,79 \mathrm{~m}^{3} / \mathrm{ha} /$ tahun dan rata-rata volume tegakan antara $119,59-244,76 \mathrm{~m}^{3} / \mathrm{ha}$.

3. Daur tebang 7 (tujuh) tahun diperoleh riap tahunan rata-rata antara $20,72-40,90 \mathrm{~m}^{3} / \mathrm{ha} /$ tahun dan rata-rata volume tegakan berkisar $145,02-286,28 \mathrm{~m}^{3} / \mathrm{ha}$.

4. Daur tebang 8 (delapan) tahun diperoleh riap tahunan rata-rata antara $20,95-40,25 \mathrm{~m}^{3} / \mathrm{ha} /$ tahun dan rata-rata volume tegakan antara $167,58-321,98 \mathrm{~m}^{3} / \mathrm{ha}$. 
Tabel (Table) 5. Daur, riap tahunan rata-rata, riap tahun berjalan dan volume tegakan untuk setiap bonita (Cycle, mean annual increment, current annual increment, and stands volume for each bonita)

\begin{tabular}{|c|c|c|c|c|}
\hline Bonita & Daur (Cycle) & $\begin{array}{c}\text { MAI } \\
\left(\mathrm{m}^{3} / \text { ha/tahun }\right) \\
\left(\mathrm{m}^{3} / \text { ha/years }\right)\end{array}$ & $\begin{array}{c}\text { CAI } \\
\left(\mathrm{m}^{3} / \text { ha/tahun }\right) \\
\left(\mathrm{m}^{3} / \text { ha/years }\right) \\
\end{array}$ & $\begin{array}{l}\text { Volume } \\
\left(\mathrm{m}^{3} / \mathrm{ha}\right)\end{array}$ \\
\hline & $\begin{array}{l}\text { Daur volume maksimum } \\
\text { (Maximum volume cycle) }\end{array}$ & & & \\
\hline $\mathrm{I}$ & 8,2 Tahun (Years) & 20,95 & 20,95 & 171,77 \\
\hline II & 8,2 Tahun (Years) & 32,40 & 32,40 & 265,67 \\
\hline III & 7,1 Tahun (Years) & 37,48 & 37,48 & 266,09 \\
\hline \multirow[t]{2}{*}{ IV } & 7,1 Tahun (Years) & 40,86 & 40,86 & 290,10 \\
\hline & Daur tebang (Cutting cycle) & & & \\
\hline I & 5 Tahun (Years) & 18,26 & 30,40 & 91,30 \\
\hline II & 5 Tahun (Years) & 28,18 & 47,04 & 140,92 \\
\hline III & 5 Tahun (Years) & 35,23 & 51,85 & 176,16 \\
\hline \multirow[t]{2}{*}{ IV } & 5 Tahun (Years) & 39,31 & 55,11 & 196,55 \\
\hline & Daur tebang (Cutting cycle) & & & \\
\hline $\mathrm{I}$ & 6 Tahun (Years) & 19,93 & 28,29 & 119,59 \\
\hline II & 6 Tahun (Years) & 30,79 & 43,83 & 184,74 \\
\hline III & 6 Tahun (Years) & 37,48 & 46,09 & 222,25 \\
\hline \multirow[t]{2}{*}{ IV } & 6 Tahun (Years) & 40,79 & 48,21 & 244,76 \\
\hline & Daur tebang (Cutting cycle) & & & \\
\hline $\mathrm{I}$ & 7 Tahun (Years) & 20,72 & 25,43 & 145,02 \\
\hline II & 7 Tahun (Years) & 32,02 & 39,43 & 224,17 \\
\hline III & 7 Tahun (Years) & 37,48 & 40,13 & 262,39 \\
\hline \multirow[t]{2}{*}{ IV } & 7 Tahun (Years) & 40,90 & 41,52 & 286,28 \\
\hline & Daur tebang (Cutting cycle) & & & \\
\hline I & 8 Tahun (Years) & 20,95 & 22,56 & 167,58 \\
\hline II & 8 Tahun (Years) & 32,40 & 34,00 & 259,17 \\
\hline III & 8 Tahun (Years) & 37,15 & 34,79 & 297,17 \\
\hline IV & 8 Tahun (Years) & 40,25 & 35,70 & 321,98 \\
\hline
\end{tabular}

\section{B. Pembahasan}

Hasil uji hubungan antara peninggi, diameter, tinggi, dan volume tegakan dengan umur tegakan membentuk model sigmoid (mengikuti bentuk S terhadap waktu). Dari hasil analisis diperoleh koefisien determinasi dan koefisien korelasi yang tinggi, nilai RMSE dan RMSPE yang kecil, dan hasil uji $\mathrm{X}^{2}$ (Khikuadrat) tidak berbeda nyata. Dengan demikian, model persamaan pada Tabel 2 dan 4 sebagai model yang handal dan sahih (valid). Hal ini sesuai dengan kriteria yang disyaratkan oleh Draper dan Smith (1998); Montgomery et al. (2001); Belsley et al. (2005); dan Kutner et al. (2005). Oleh karena itu, persamaan tersebut layak dipergunakan untuk praktek lapangan. Dengan kata lain, penggunaan persamaan tersebut untuk menduga peninggi, diameter, tinggi, dan volume tegakan eukaliptus di PT Toba Pulp Lestari Sektor Aek Nauli dalam praktek 
inventarisasi hutan mengandung resiko kesalahan dugaan yang kecil.

Laju pertumbuhan diameter eukaliptus ratarata meningkat cukup cepat sampai umur kurang dari 2 (dua) tahun, kemudian laju pertumbuhan diameter menurun secara tajam sampai tahun keempat. Laju pertumbuhan tinggi rata-rata meningkat pesat sampai berumur 2 (dua) tahun, lalu menurun tajam sampai umur 5 (lima) tahun. Laju pertumbuhan volume tegakan rata-rata meningkat dengan pesat pada umur 3 - 8 tahun, dan selanjutnya sampai tahun kesepuluh laju pertumbuhan volume tegakan menurun drastis. Laju pertumbuhan tegakan dari lokasi yang satu dengan lokasi lainnya tidak sama, hal ini karena tingkat pertumbuhan tegakan dipengaruhi oleh komponen penyusun ekosistem. Komponen ekosistem tersebut saling berpengaruh dan terkait satu sama lain secara simultan. Faktor-faktor yang mempengaruhi pertumbuhan tegakan yaitu faktor genetik, lingkungan, dan tindakan silvikultur (Kramer dan Kozlowski, 1960).

Dari hasil analisis ditetapkan umur indeks untuk tegakan eukaliptus di hutan tanaman PT Toba Pulp Lestari Sektor Aek Nauli adalah delapan tahun. Umur 8 (delapan) tahun merupakan daur volume maksimum tegakan eukaliptus di hutan tanaman PT Toba Plup Lestari. Hal ini sesuai dengan ketentuan bahwa penetapan umur indeks berdasarkan daur volume maksimum yaitu umur tegakan dimana hasil kayu tahunan mencapai volume yang tertinggi. Umur ini ditunjukkan oleh perpotongan antara kurva riap tahun berjalan (CAI) dengan kurva riap tahunan rata-rata (MAI) (Simon, 2010). Pada daur 8 (delapan) tahun diperoleh rata-rata:

1. Diameter $17,1 \mathrm{~cm}$ dengan MAI $1,9 \mathrm{~cm} /$ tahun, dan CAI $0,4 \mathrm{~cm} / \mathrm{tahun}$,

2. Tinggi 20,9 m dengan MAI 2,3 m/tahun, dan CAI 0,5 m/tahun,

3. Volume tegakan $249,34 \mathrm{~m}^{3} /$ ha dengan MAI $31,17 \mathrm{~m}^{3} / \mathrm{ha} /$ tahun, dan CAI $31,52 \mathrm{~m}^{3} / \mathrm{ha} /$ tahun.

Hasil penelitian menunjukkan bahwa terdapat keberagaman nilai indeks tempat tumbuh di hutan tanaman eukaliptus PT TPL Sektor Aek Nauli. Keragaman nilai indeks tempat tumbuh tersebut menyebabkan potensi tegakan berbeda antara satu lokasi dengan lokasi lainnya. Faktor yang mempengaruhi keragaman nilai indeks tempat tumbuh adalah adanya perbedaan pertumbuhan peninggi tegakan eukaliptus. Perbedaan pertumbuhan peninggi tegakan eukaliptus di hutan tanaman PT TPL Sektor Aek Nauli dipengaruhi oleh kualitas tempat tumbuh, sedangkan faktor lainnya diperlakukan yang sama. Seperti jenis yang ditanam menggunakan jenis yang sama yaitu E. urograndis (persilangan antara E. urophylla dan E. grandis), dan perlakuan silvikultur (penyiapan lahan, jarak tanam, pemupukan, dan pemeliharaan) dilakukan sama. Teknik silvikultur dapat diterapkan terhadap tanah dan pengelolaan tegakan untuk meningkatkan ketersediaan air dan unsur hara selama pertumbuhan. Pada hutan tanaman cepat tumbuh, penerapan pengelolaan tegakan dengan teknik silvikultur intensif dapat menaikkan dan mempertahankan produktivitas. Pada umumnya pengelolaan intensif dilakukan pada fase persiapan bibit, persiapan lahan dan fase pemeliharaan tegakan berupa pemberian input hara atau pemupukan (Nambiar, 1996).

Dari hasil pengkelasan kualitas tempat tumbuh (bonita) telah terjadi daur volume maksimum yang berbeda, yaitu untuk bonita I dan II daur volume maksimum pada umur 8,2 tahun, sedangkan pada bonita III dan IV terjadi pada umur 7,1 tahun. Hal ini menunjukkan bahwa di kawasan hutan tanaman eukaliptus di PT Toba Pulp Lestari Sektor Aek Nauli terjadi perbedaan kualitas tempat tumbuh yang menyebabkan potensi tegakan berbeda antara satu lokasi dengan lokasi lainnya. Hal ini terjadi juga di tempat lain bahwa riap jenis-jenis eukaliptus sangat beragam tergantung faktor lingkungan dan managemen yang diterapkan. Di Brazil, MAI eukaliptus dengan daur tebang 8 - 10 tahun mencapai $18-20 \mathrm{~m}^{3} / \mathrm{ha} /$ tahun. Di Kongo dengan daur tebang 7 (tujuh) tahun mencapai $30 \mathrm{~m}^{3} / \mathrm{ha} /$ tahun, di Rwanda pada daur tebang 8 (delapan) tahun menghasilkan $8,5 \mathrm{~m}^{3} /$ ha/tahun, di Afrika Selatan dengan daur tebang 8 - 10 tahun mencapai 18 - $20 \mathrm{~m}^{3} / \mathrm{ha} /$ tahun, dan di Burundi pada daur tebang 8 (delapan) tahun hanya mencapai $1-2$ m/ha/tahun (FAO, 1993; Nambiar \& Brown, 1997). MAI Eucalyptus urograndis di Brazil sebesar $30 \mathrm{~m}^{3} / \mathrm{ha} /$ tahun pada curah hujan kurang dari $1.000 \mathrm{~mm} /$ tahun, curah hujan antara $1.000-1.200 \mathrm{~mm} /$ tahun sekitar $30-37$ $\mathrm{m}^{3} /$ ha/tahun, sedangkan pada areal yang mempunyai curah hujan lebih dari $1.200 \mathrm{~mm} /$ tahun MAI mencapai $38-58 \mathrm{~m}^{3} / \mathrm{ha} /$ tahun (Fisher dan Binkley 2000). Sedangkan di Afrika Selatan dan Kongo sangat tinggi dengan MAI sebesar 70 $\mathrm{m}^{3} /$ ha/tahun (Campinhos, 1993). Dengan demikian, riap tegakan eukaliptus di hutan tanaman PT Toba Pulp Lestari bisa menyamai di Brazil pada kondisi curah hujan antara $1.000-1.200$ $\mathrm{mm} /$ tahun. 
Daur tebang 5 (lima) tahun diperoleh riap tahunan rata-rata antara $18,26-39,31 \mathrm{~m} 3 / \mathrm{ha} /$ tahun. Mindawati et al. (2010) menyatakan bahwa Eucalyptus urograndis di lokasi yang sama pada umur kurang dari 6 (enam) tahun, ketersediaan unsur hara dalam tanah masih lebih rendah daripada hara yang keluar. Penelitian menunjukkan bahwa target $40 \mathrm{~m}^{3} / \mathrm{ha} /$ tahun dapat dicapai pada daur 6 - 8 tahun dan hanya ada di bonita IV, sedangkan di bonita I, II, dan III masih dibawah $40 \mathrm{~m}^{3} / \mathrm{ha} /$ tahun. Dalam penetapan daur tebang tidak hanya memperhatikan produksi kayu saja, tetapi harus memperhatikan aspek lainnya diantaranya tingkat produktivitas lahan dan aspek lingkungan. Pengelompokan kualitas tempat tumbuh merupakan upaya dalam pengaturan hasil yang memperhatikan tingkat produktivitas lahan. Dari aspek lingkungan dapat dilihat dari keseimbangan neraca hara dan dampak erosi yang terjadi. Sedangkan dari aspek erosi tanah, dari hasil penelitian menunjukkan bahwa di hutan tanaman Acacia mangium selama 3 (tiga) tahun pertama setelah tanam telah menimbulkan aliran permukaan yang tinggi sehingga menimbulkan erosi tanah yang tinggi, hal ini diakibatkan tajuk tanaman belum menutupi lahan (Pratiwi, 2007).

Oleh karena itu, daur 5 (lima) tahun tidak tepat karena masih terjadi defisit unsur hara dan produktivitas tegakan belum maksimum. Meskipun dari segi teknis tanaman eukaliptus merupakan jenis yang cocok dikembangkan di daerah tropis (Harwood, 1998; Leksono, 2010) yang dapat dipanen pada umur 6 - 7 tahun (Harmoko, 2004; Quilho et al., 2006), dan layak untuk digunakan sebagai bahan baku pulp pada umur 4 - 5 tahun (Sihite, 2008). Diameter tegakan telah memenuhi syarat untuk bahan baku pulp (Iskandar, 2004), syarat diameter untuk pabrik pulp minimal 8 (delapan) $\mathrm{cm}$. PT TPL telah menetapkan batas minimal diameter cabang dan batang pohon untuk bahan baku serpih (chip) sebesar lima $\mathrm{cm}$. Dengan memperhatikan hal tersebut, maka daur eukaliptus di PT Toba Pulp Lestari Sektor Aek Nauli yang tepat adalah 8 (delapan) tahun.

Pada daur tebang 8 (delapan) tahun antar bonita menunjukkan riap tahunan rata-rata dan volume tegakan relatif berbeda. Oleh karena itu, pengelompokan kualitas tempat tumbuh perlu dibuat di hutan tanaman eukaliptus tersebut karena pengkelasan kualitas tempat tumbuh merupakan perangkat yang diperlukan dalam perencanaan pengelolaan hutan tanaman. Hal ini untuk menghindari terjadi fluktuasi produksi kayu setiap tahunnya.

\section{KESIMPULAN DAN SARAN}

\section{A. Kesimpulan}

1. Riap volume maksimum tegakan eukaliptus sebesar $31,13 \mathrm{~m}^{3} / \mathrm{ha} /$ tahun yang terjadi pada umur 8,1 tahun sehingga daur volume maksimum dan umur indeks tempat tumbuh ditetapkan 8 (delapan) tahun dengan rata-rata volume tegakan $249,34 \mathrm{~m}^{3} / \mathrm{ha}$ dan riap tahunan rata-rata $31,17 \mathrm{~m}^{3} /$ ha/tahun.

2. Model persamaan model indeks tempat tumbuhnya adalah $\log \mathrm{S}=\log \mathrm{Oh}+$ $0.69441\left(\mathrm{~A}^{-1}-8^{-1}\right)$ dan telah dibuat 4 (empat) kelas kualitas tempat tumbuh (bonita).

3. Pada daur 8 (delapan) tahun riap tahunan ratarata di bonita I, II, III, dan IV berturut-turut adalah $20,95 \mathrm{~m}^{3} / \mathrm{ha} /$ tahun, $32,40 \mathrm{~m}^{3} / \mathrm{ha} /$ tahun, $37,15 \mathrm{~m}^{3} / \mathrm{ha} /$ tahun, dan $40,25 \mathrm{~m}^{3} / \mathrm{ha} /$ tahun. Rata-rata volume tegakan berturut-turut adalah $167,58 \mathrm{~m}^{3} / \mathrm{ha}, 259,17 \mathrm{~m}^{3} / \mathrm{ha}, 297,17$ $\mathrm{m}^{3} / \mathrm{ha}$, dan $321,98 \mathrm{~m}^{3} / \mathrm{ha}$.

\section{B. Saran}

1. Daur tebang tidak hanya ditentukan berdasarkan produksi kayu saja, tetapi perlu juga mempertimbangkan aspek keseimbangan antara ketersediaan unsur hara yang tersedia dengan unsur hara yang keluar, dan tingkat bahaya erosi yang terjadi.

2. Etat tebang di hutan tanaman perlu dikelompokkan berdasarkan kelas kualitas tempat tumbuh (bonita).

\section{DAFTAR PUSTAKA}

Alder, D. 1980. Forest Volume Estimation and Yield Prediction. FAO. Rome.

Anonim. 1986. Pedoman Penjarangan Hutan Industri. Surat Keputusan Nomor 289/ KPTS/DIR/1986. Perum Perhutani. Jakarta.

Avery, T.E. and H.E. Burkhart. 2002. Forest Measurements. McGraw-Hill. New York.

Belsley, D.A., E. Kuh, and R.E. Welsch. 2005. Regression Diagnostics: Identifying Influential Data and Sources of Collinearity. Wiley-Interscience. Hoboken. 
Campinhos, E.N. 1993. A Brazilian Example of a Large Scale Forestry Plantation in Tropical Region: Aracruz. In: J. Davinson (ed.). Proceedings of the Regional Symposium on Recent Advances in Mass Clonal Multiplication of Forest Trees for Plantation Programmes. FAO, Los Banos, Philipines: 46-59.

Draper, N.R., and H. Smith. 1998. Applied Regression Analysis. Third Edition. John Wiley \& Sons, Inc. Sydney.

FAO. 1993. Forest Resource Assesssment 1990. Tropical Countries. Food and Agriculture Organization of the United Nations. Rome.

Fisher, R.F. and D. Binkley. 2000. Ecology and Management of Forest Soil. John Willey \& Sons, Inc.

Harbagung. 2009. Model Hubungan Tinggi Tegakan dengan Peninggi pada Hutan Tanaman Jati (Tectona grandis L.f.). Jurnal Penelitian Hutan Tanaman. Vol. 8 (2): 109-123.

Harwood, C.E. 1998. Eucalyptus pellita an Annotated Bibliography. CSIRO Publishing, Victoria, Australia.

Husch, B, T.W. Beers, and J.A. Kershaw. 2003. Forest Mensuration. Fourth Edition. John Wiley and Sons, Inc. New York.

Iskandar, U. 2004. Kebijakan Pembangunan Hutan Tanaman Industri. Dalam Hardiyanto, E.B. dan H. Arisman. 2004. Pembangunan Hutan Tanaman Acacia mangium (Pengalaman di PT. Musi Hutan Persada, Sumatera Selatan). PT. Musi Hutan Persada. Palembang. Hal.: 4389.

Kramer, P.J. dan T.T. Kozlowski. 1960. Physiology of Trees. Mc Graw-Hill Book Co., New York Toronto London.

Kuncahyo, B. 2006. Model Simulasi Pengaturan Hasil Lestari yang Berbasis Kebutuhan Masyarakat Desa Hutan. Disertasi. Pascasarjana. Institut Pertanian Bogor. Bogor. Tidak diterbitkan.

Kutner, M.H., C.J. Nachtsheim, J. Neter, dan W. Li. 2005. Applied Linier Statistical Models. McGraw-Hill Irwin. Boston.

Leksono, B. 2010. Efisiensi Seleksi Awal pada Kebun Benih Semai Eucalyptus pellita.
Jurnal Penelitian Pusat Penelitian dan Pengembangan Hutan Tanaman. Vol. 7 (1): $1-13$.

Mattjik, A.A. dan M. Sumertajaya. 2002. Perancangan Percobaan dengan Aplikasi SAS dan Minitab, Jilid 1. IPB Press. Bogor.

Mindawati, N., A. Indrawan, I. Mansur, dan O. Rusdiana. 2010. Kajian Pertumbuhan Tegakan Hybrid Eucalyptus urograndis di Sumatera Utara. Jurnal Penelitian Hutan Tanaman. Vol. 7(1):39- 50.

Montgomery, D.C., A.E. Peck, and G.G. Vining. 2001. Introduction to Linear Regression Analysis. Wiley. New York.

Nambiar, E.K.S. 1996. Sustained productivity of forest is a continuing challenge to Soil Science. Soil Science Society of America Journal 60. 1629-1642.

Nambiar, E.K.S. and A.G. Brown. 1997. Toward Sustained Productivity of Tropical Plantations: Science and Practice. In: Nambiar, E.K.S and A.G. Brown. (eds). Management of Soil, Nutrients and Water in Tropical Plantation Forest ACIAR, CSIRO and CIFOR: 527-557.

Pratiwi. 2007. Laju Aliran Permukaan dan Erosi di Beberapa Hutan Tanaman dan Beberapa Alternatif Upaya Perbaikannya. Jurnal Penelitian Hutan dan Konservasi Alam. Vol. 4(3): 267-276.

Prodan, M. 1968. Forest Biometrics. Perganon. Oxford-London.

Quilhó, T., I. Miranda, and H. Pereira. 2006. Within-tree variation in Wood Fibre Biometry and Basic Density of the Urograndis Eucalypt Hybrid (Eucalyptus grandis $x$ E. urophylla). Journal IAWA, Vol. 27 (3): 243254.

Sihite, O. 2008. Hubungan Umur Pohon Eucalyptus sp. dengan Kandungan Pentosan Bahan Baku Pulp pada PT Toba Pulp Lestari. Tesis. Pascasarjana Universitas Sumatera Utara. Medan. Tidak diterbitkan.

Simon, H. 2010. Perencanaan Pembangunan Sumberdaya Hutan. Jilid I.A. Celeban Timur. Yogyakarta.

Supranto, J. 2005. Ekonometri: Buku Satu. Ghalia Indonesia. Bogor. 